\title{
Effects of cytarabine on activation of human T cells - cytarabine has concentration-dependent effects that are modulated both by valproic acid and all-trans retinoic acid
}

Elisabeth Ersvaer ${ }^{1,2^{*}}$, Annette K Brenner ${ }^{1}$, Kristin Vetås ${ }^{1}$, Håkon Reikvam ${ }^{1}$ and Øystein Bruserud ${ }^{1,3}$

\begin{abstract}
Background: Cytarabine is used in the treatment of acute myeloid leukemia (AML). Low-dose cytarabine can be combined with valproic acid and all-trans retinoic acid (ATRA) as AML-stabilizing treatment. We have investigated the possible risk of immunotoxicity by this combination. We examined the effects of cytarabine combined with valproic acid and ATRA on in vitro activated human T cells, and we tested cytarabine at concentrations reached during in vivo treatment with high doses, conventional doses and low doses.
\end{abstract}

Methods: T cells derived from blood donors were activated in vitro in cell culture medium alone or supplemented with ATRA $(1 \mu \mathrm{M})$, valproic acid (500 or $1000 \mu \mathrm{M})$ or cytarabine $(0.01-44 \mu \mathrm{M})$. Cell characteristics were assessed by flow cytometry. Supernatants were analyzed for cytokines by ELISA or Luminex. Effects on primary human AML cell viability and proliferation of low-dose cytarabine (0.01-0.5 $\mu \mathrm{M}$ ) were also assessed. Statistical tests include ANOVA and Cluster analyses.

Results: Only cytarabine $44 \mu \mathrm{M}$ had both antiproliferative and proapoptotic effects. Additionally, this concentration increased the CD4:CD8 T cell ratio, prolonged the expression of the CD69 activation marker, inhibited CD95L and heat shock protein (HSP) 90 release, and decreased the release of several cytokines. In contrast, the lowest concentrations $(0.35$ and $0.01 \mu \mathrm{M})$ did not have or showed minor antiproliferative or cytotoxic effects, did not alter activation marker expression (CD38, CD69) or the release of CD95L and HSP90, but inhibited the release of certain $T$ cell cytokines. Even when these lower cytarabine concentrations were combined with ATRA and/or valproic acid there was still no or minor effects on T cell viability. However, these combinations had strong antiproliferative effects, the expression of both CD38 and CD69 was altered and there was a stronger inhibition of the release of FasL, HSP90 as well as several cytokines. Cytarabine (0.01-0.05 $\mu \mathrm{M})$ showed a dose-dependent antiproliferative effect on AML cells, and in contrast to the T cells this effect reached statistical significance even at $0.01 \mu \mathrm{M}$.

Conclusions: Even low levels of cytarabine, and especially when combined with ATRA and valproic acid, can decrease T cell viability, alter activation-induced membrane-molecule expression and decrease the cytokine release.

Keywords: $T$ cells, Cytarabine, All-trans retinoic acid, Valproic acid, Acute myeloid leukemia

\footnotetext{
* Correspondence: elisabeth.ersver@hib.no

'Institute of Clinical Science, University of Bergen, Bergen, Norway

${ }^{2}$ Institute of Biomedical Laboratory Sciences, Bergen University College,

Nygårdsgaten 112, P.O. Box 7030, N-5020 Bergen, Norway

Full list of author information is available at the end of the article
} 


\section{Background}

Intensive anticancer therapy causes an acute and severe panleukopenia, including $\mathrm{T}$ lymphopenia, that may last for 2-4 weeks [1], and after hematopoietic reconstitution these patients usually develop a $\mathrm{CD} 4^{+} \mathrm{T}$ cell defect that may persist for several months especially in adults [2]. This persisting $\mathrm{T}$ cell defect has been described both after conventional chemotherapy as well as after autologous and allogeneic stem cell transplantation. All these three therapeutic strategies are used in the treatment of acute myeloid leukemia (AML), and early lymphocyte recovery after such intensive treatment then predicts superior relapse-free survival. This observation suggests that early immunological events [3-6] and possibly also cancer- or AML-related inflammation [7] are important for AML cell survival and proliferation after chemotherapy.

Even though AML is an aggressive malignancy and intensive chemotherapy eventually in combination with stem cell transplantation is the most effective antileukemic therapy [8], many elderly or unfit patients cannot receive this treatment due to an unacceptable risk of severe toxicity and early treatment-related mortality. These patients will either receive supportive care alone or in combination with low-toxicity AML-stabilizing chemotherapy [8]. One such low-toxicity AML stabilizing chemotherapy is single-drug, low-dose subcutaneous cytarabine injections usually administered as daily treatment for 10 days with 4-6 weeks intervals; this treatment can eventually be combined with oral all-trans retinoic acid (ATRA) and valproic acid, i.e. a histone deacetylase inhibitor [9-14]. Previous in vivo clinical studies have shown that the triple combination of low-dose cytarabine, ATRA and valproic acid has immunomodulatory effects through a normalization of the increased pretherapy levels of circulating Treg cells, whereas the levels of Th17 cells are not affected by the treatment [15]. However, very little is known both about the acute and longterm effects of such treatment on the $\mathrm{T}$ cell system and whether $\mathrm{T}$ cell toxicity affects its antileukemic efficiency. In the present study we therefore investigated the in vitro effects of various cytarabine concentrations, valproic acid and ATRA on activated T cells.

\section{Methods}

\section{Cell donors and preparation of peripheral blood mononuclear cells}

The studies were approved by the local Ethics Committee (Regional Ethics Committee III, University of Bergen, Bergen, Norway) and buffy coats were derived from healthy blood donors after informed consent. Peripheral blood mononuclear cells (PBMC) were isolated by density gradient separation (Ficoll-Hypaque; NyCoMed, Oslo, Norway; specific density 1.077) from buffy coats from seven healthy blood donors (median age 29 years; 3 male and 4 female). Viability, proliferation and cytokine release was examined for all individuals, CD4:CD8 ratio and expression of activation markers were investigated only for 3 randomly selected individuals.

\section{Drugs}

Cytarabine (Cytosine $\beta$-D-arabinofuranoside; SigmaAldrich, USA) was dissolved in $\mathrm{ddH}_{2} \mathrm{O}$ to obtain a concentration of $400 \mu \mathrm{M}$ before aliquoted, ATRA (SigmaAldrich; Oslo, Norway) was dissolved in 96\% ethanol to $1 \mathrm{mM}$ and valproic acid (Desitin Arzneimittel GmbH, Hamburg, Germany) was diluted in saline to $60 \mathrm{mM}$. All drugs were stored at $-80^{\circ} \mathrm{C}$. Drugs were thawed on the same day they were used in experiments and based on previous studies of in vivo levels the drugs were tested at the following concentrations that are relevant to low-toxicity AML treatment: valproic acid $1000 \mu \mathrm{M}$ and $500 \mu \mathrm{M}$ [16], cytarabine $0.35 \mu \mathrm{M}$ and $0.01 \mu \mathrm{M}$ [17-19], and ATRA $1 \mu \mathrm{M}$ [20-22]. Cytarabine was also tested at $44 \mu \mathrm{M}$ and $1 \mu \mathrm{M}$ corresponding to high-dose therapy $[23,24]$. The relevance of these 4 cytarabine concentrations with regard to the levels reached in vivo is discussed in detail below in the Discussion section.

\section{Cell culture}

PBMC were suspended in pre-warmed $\mathrm{X}$-Vivo $10^{\circ}$ medium (BioWhittaker, Cambridge, MA, USA) with 10\% FBS (Lonza Braine, Belgium) and cultured in 24-well culture plates at a final concentration of $0.5 \times 10^{6}$ cells $/ \mathrm{mL}$ (viability and proliferation analyses) or $1 \times 10^{6}$ cells $/ \mathrm{mL}$ (analysis of activation markers). T lymphocytes were activated by 0.6 $\mu \mathrm{g} / \mathrm{mL}$ of mouse anti-human CD3 (Pelicluster, Amsterdam, The Netherlands) and $0.4 \mu \mathrm{g} / \mathrm{mL}$ of mouse anti-human CD28 (Pelicluster). Drugs were prepared from frozen stock solutions the same day as the experiments. Cultures were incubated at $37^{\circ} \mathrm{C}$ in a humidified atmosphere of $5 \% \mathrm{CO}_{2}$ before cells/supernatants were harvested.

\section{Flow cytometric analysis of viability, proliferation and membrane molecule expression}

Flow cytometry was performed by FACS Canto II. For each sample at least $20000 \mathrm{CD}^{+}$lymphocytes were counted. All results were analyzed by FlowJo software (Tree Star, Inc., OR, USA).

\section{Proliferation and viability assay}

PBMC dissolved in PBS were stained strictly according to the manufacturer's instructions in the CellTrace Violet Cell Proliferation Kit (Invitrogen); thereafter cells were washed and cultures prepared as described above. The cells were harvested after 4 days and washed in ice-cold PBS before being resuspended in Annexin V Bindings buffer (BD Biosciences, Trondheim, Norway) and stained for 15 minutes with LIVE/DEAD Far Red Fixable Dead 
Cell Stain (Invitrogen, Oregon, USA). Annexin V conjugated with Alexa488 (Invitrogen, Oregon, USA) and antihuman CD5 conjugated with PE-CY7 (clone L17F12; BD) was added, cells were further incubated for 15 minutes and thereafter washed in ice-cold 1\% BSA/PBS before four-color flow cytometric analysis.

\section{Analysis of CD4/CD8 ratio and activation marker expression} Cells were harvested after 20, 44 and 68 hours of culture, thereafter washed in ice-cold 1\% BSA/PBS followed by 10 minutes of incubation in $200 \mu \mathrm{g} / \mathrm{ml}$ of Fc-receptor blocking agent (Octagam, Octapharma Ltd, Coventry, UK) before the following anti-human antibodies were added; FITC-conjugated anti-CD5 (L17F12; BD Biosciences), V500-conjugated anti-CD8 (RPA-T8; BD Biosciences), PerCPCy5.5-conjugated anti-CD4 (RPA-T4; BD Pharmingen), PE-conjugated anti-CD25 (M-A251; BD Biosciences), PE-CY7-conjugated anti-CD69 and APC-conjugated anti-CD38. Cells were incubated with antibodies on ice for 20 minutes, washed once in $1 \%$ BSA/PBS and finally analyzed by flow cytometry.

\section{Analysis of soluble mediator concentrations Luminex analyses}

Culture supernatants were harvested after 4 days and stored at $-80^{\circ} \mathrm{C}$ until analyzed. Cytokine levels were determined by Human Cytokine Panel A Fluorokine ${ }^{\odot}$ Multianalyte Profiling (MAP) Kit (LUH000; R\&D Systems, Abingdon, UK). All analyses were performed strictly according to the manufacturer's instructions. Standard curves were constructed by using the mean of duplicate determinations, and differences between duplicates were generally $<10 \%$ of the mean. The minimal detectable levels were IFN $\gamma 1.27 \mathrm{pg} / \mathrm{mL}, \mathrm{TNF}-\alpha 1.5 \mathrm{pg} / \mathrm{mL}$, G-CSF 1.48 pg/mL, GM-CSF 1.98 pg/mL, VEGF 1.84 $\mathrm{pg} / \mathrm{mL}$, bFGF $4.91 \mathrm{pg} / \mathrm{mL}$, IL1RA $10.91 \mathrm{pg} / \mathrm{mL}$, IL1 $\alpha$ $0.36 \mathrm{pg} / \mathrm{mL}$, IL1ß $0.57 \mathrm{pg} / \mathrm{mL}$, IL2 2.23 pg/mL, IL4 4.46 pg/ mL, IL5 $0.71 \mathrm{pg} / \mathrm{mL}$, IL6 $1.11 \mathrm{pg} / \mathrm{mL}$, IL8 $1.97 \mathrm{pg} / \mathrm{mL}$ (CXCL8), IL10 0.30 pg/mL, IL17 1.1 pg/mL, CCL2 (MCP-1) $0.47 \mathrm{pg} / \mathrm{mL}$, CCL3 (MIP-1 $\alpha) 1.45 \mathrm{pg} / \mathrm{mL}$, CCL4 (MIP-1 $\beta$ ) $0.74 \mathrm{pg} / \mathrm{mL}$, CCL5 (RANTES) $1.91 \mathrm{pg} / \mathrm{mL}$, CXCL5 (ENA78) $4.14 \mathrm{pg} / \mathrm{mL}$.

\section{Enzyme-linked immuno-sorbent analyses (ELISA)}

Supernatants were harvested and stored as described above. Mediator levels were determined by HSP90 $\alpha$ human EIA kit (ADI-EKS-895; Enzo Life Sciences, Exeter, UK), HSP70 high sensitivity ELISA kit (ADI-EKS-715; Enzo Life Science) TRAIL/TNFSF10 immunoassay (Quantikine, R\&D Systems), human CD95/Fas Ligand/TNFSF6 immunoassay (Quantikine, R\&D Systems). All analyses were performed strictly according to the manufacturer's instructions. Standard curves were constructed based on the mean of duplicate determinations, and differences between duplicates were generally $<10 \%$ of the mean. The minimal detectable levels were HSP90 $0.05 \mathrm{ng} / \mathrm{mL}$, HSP70 0.09 ng/mL, FasL 2.26 pg/mL, TRAIL 2.86 pg/mL.

\section{AML patient samples and analyses}

The effect of low-doses cytarabine were also tested on primary human AML cells from 48 consecutive patients (median age 67 years; range 24-83 years; 23 female and 25 male). Our strategy for recruitment of consecutive patients has been described in detail previously [25]. All patients were tested at the time of diagnosis before they eventually received antileukemic treatment. The AML cells were isolated from peripheral blood using density gradient separation (Lymphoprep; Axis Shield, Oslo, Norway) and contained at least $90 \%$ blasts. For cell viability measurement, AML cells $\left(2 \times 10^{5}\right.$ cells/well $)$ were incubated in flat-bottomed microtiter plates $(200 \mu \mathrm{l} /$ well; Costar 3596 culture plates; Costar, Cambridge, MA, USA) in Stem Span SFEM ${ }^{\mathrm{rm}}$ medium (Stem Cell Technologies; Vancouver, $\mathrm{BC}$, Canada) at $37^{\circ} \mathrm{C}$ in a humidified $5 \% \mathrm{CO}_{2}$ incubator for 40 hours before the percentage of viable cells was determined by flow cytometry after staining with propidium iodide (PI) and Annexin V. Furthermore, for the proliferation assay $5 \times 10^{4} \mathrm{AML}$ cells/well were cultured in flat-bottomed microtiter plates $(200 \mu \mathrm{l} /$ well $)$ in Stem Span for six days prior to addition of $37 \mathrm{kBq}$ of ${ }^{3} \mathrm{H}$-thymidine (Perkin Elmer) to each well and incubated for 18 hours before cells were harvested and radioactive activity determined. The medium used in the proliferation assay was supplemented with the growth factors $(20 \mathrm{ng} / \mathrm{ml})$ G-CSF, SCF and Flt3l.

\section{Statistical analyses}

Statistical comparisons were made by using GraphPad PRISM (version 5.0, GraphPad Software, Inc., USA) with repeated measures ANOVA (within-subjects ANOVA or ANOVA for correlated samples) with Dunnett's Multiple Comparison Test (post-test). Differences were regarded as significant when $\mathrm{p}<0.05$. Cluster analyses were performed by the use of J-Express 2011 analysis suite (MolMine AS, Bergen, Norway). The AML cell data were analysed with the IBM Statistical Package for the Social Sciences (SPSS) version 21 using pair sampled t-test and the Wilcoxon signed rank test to compare drug-containing and drugfree cultures.

\section{Results}

ATRA and low doses of valproic acid do not affect viability and proliferative capacity of activated normal $T$ cells, whereas cytarabine has a dose-dependent antiproliferative and proapoptotic effect

PBMC derived from healthy blood donors $(n=7)$ were activated in vitro with anti-CD3 plus anti-CD28 during 4 days of culture in medium alone or medium 
supplemented with ATRA $1 \mu \mathrm{M}$, valproic acid 500 and $1000 \mu \mathrm{M}$ or cytarabine 0.01-44 $\mu \mathrm{M}$. The viability (Figure 1; Annexin-PI assay) and proliferation (Figure 2; the CellTrace Violet Cell proliferation assay) of $\mathrm{CD}^{+} \mathrm{T}$ cells were then analyzed by flow cytometry. ATRA and valproic acid $(500 \mu \mathrm{M})$ did not cause any statistically significant alteration of $\mathrm{T}$ cell viability or proliferation. A small, but statistically significant, decrease in proli feration was detected after exposure to valproic acid $(1000 \mu \mathrm{M})$. In contrast, cytarabine caused a dosedependent reduction both in viability and proliferation. An increased fraction of apoptotic cells was then detected together with the decreased viability in the cytarabine-containing cultures; an observation suggesting that the decreased viability is caused by drug-induced apoptosis.

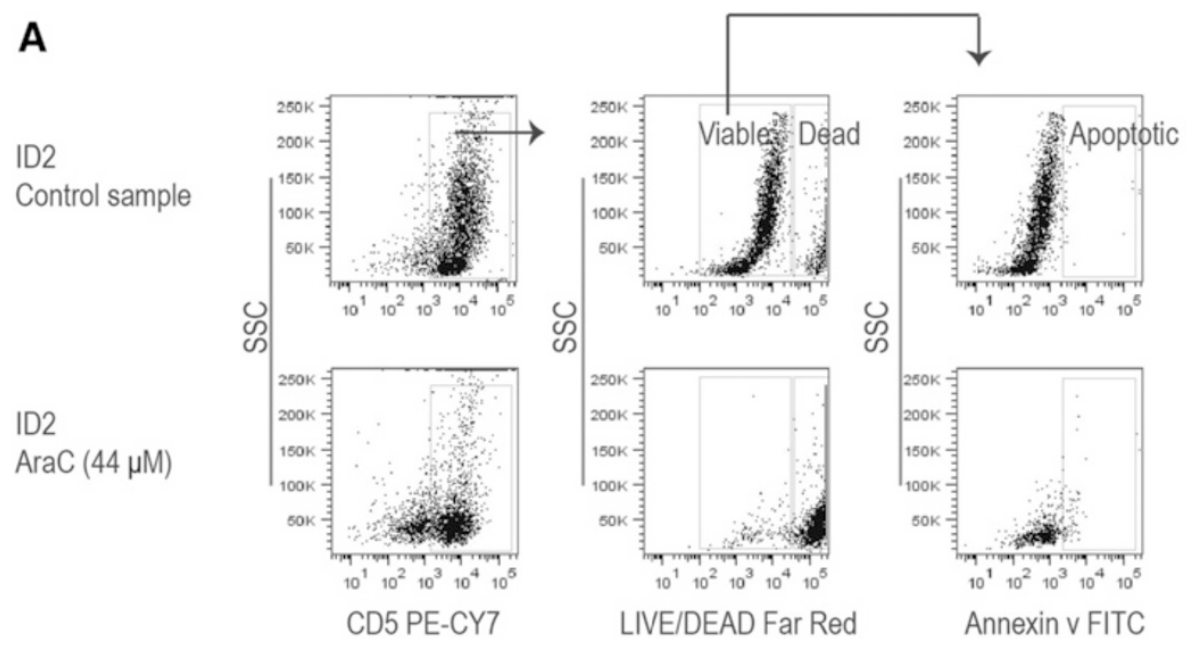

B

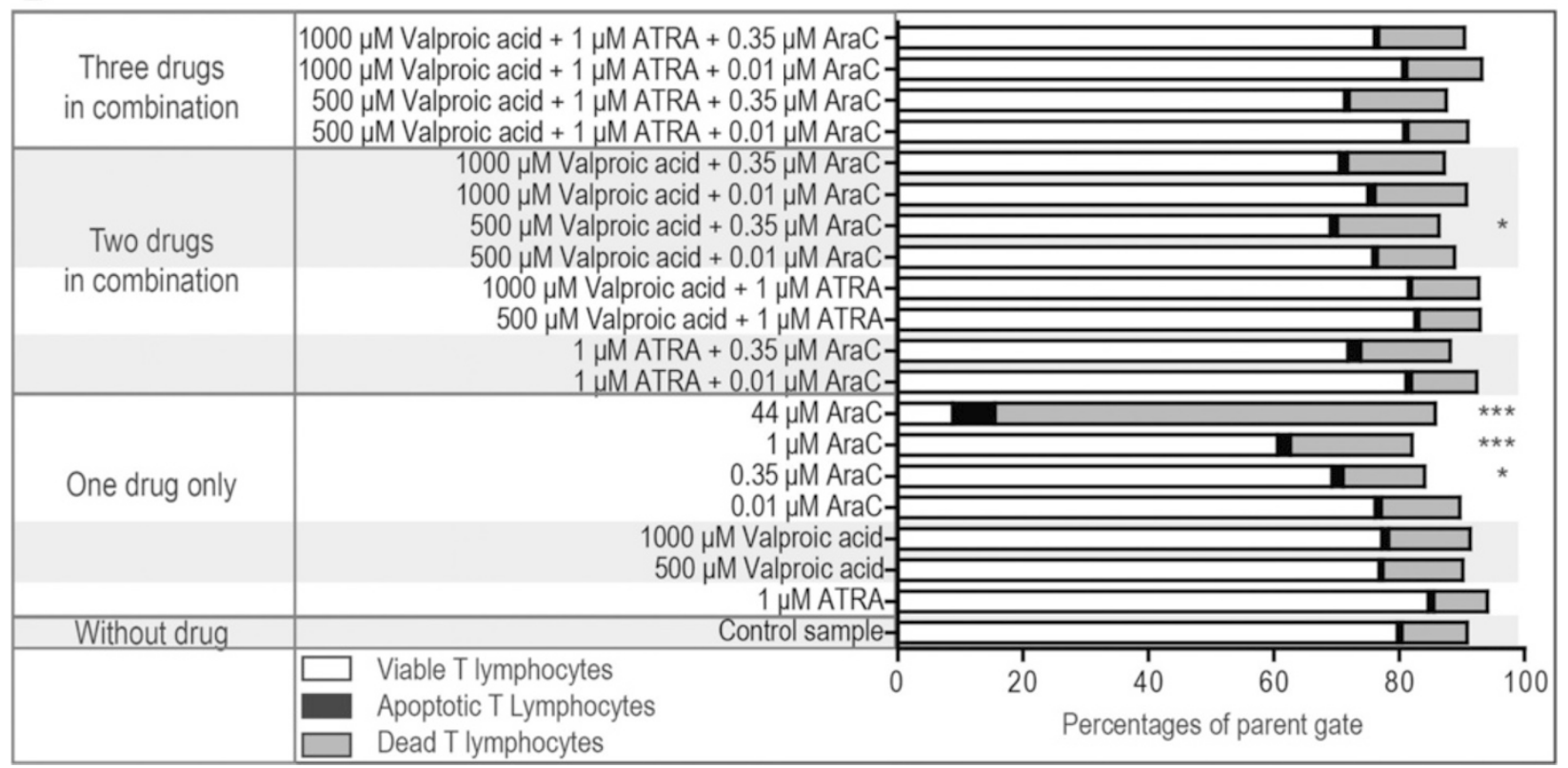

Figure 1 Viability of activated T lymphocytes after exposure to cytarabine, ATRA and valproic acid alone or in combinations. PBMCs derived from healthy blood donors $(n=7)$ were cultured in vitro with T cell activating anti-CD3 and anti-CD28, and the viability was analyzed by flow cytometry after 4 days of culture in medium alone or with the indicated drugs. (A) The gating strategy to analyze the viability of $C D 5^{+} \mathrm{T}$ lymphocytes is shown for a control sample and the corresponding sample of cells exposed to cytarabine $44 \mu \mathrm{M}$. T cells were defined as (i) viable when negative staining with the LIVE/DEAD Far Red Fixable Dead Cell Stain, (ii) apoptotic when being LIVE/DEAD Far Red Fixable Dead Cell Stain negative and Annexin V positive, and (iii) dead when being LIVE/DEAD Far Red Fixable Dead Cell Stain positive. (B) The overall results are summarized as stacked bar graphs for the control samples and samples exposed to the indicated drugs or drug combinations. The results are presented as the mean percentages for viable, dead and apoptotic $\mathrm{CD}^{+} \mathrm{T}$ cells. A repeated measure ANOVA with Dunnett's Multiple Comparison Test was used to determine statistically significant differences $\left({ }^{*} p<0.05 ;{ }^{* *} p<0.01 ;{ }^{* *} p<0.001\right)$. 


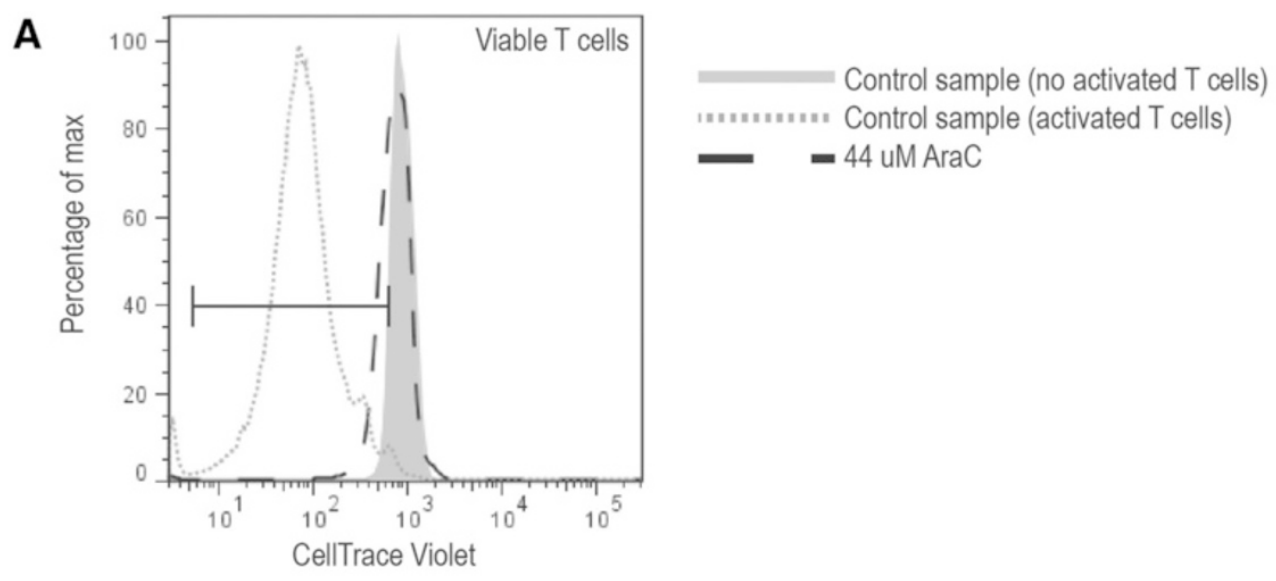

B

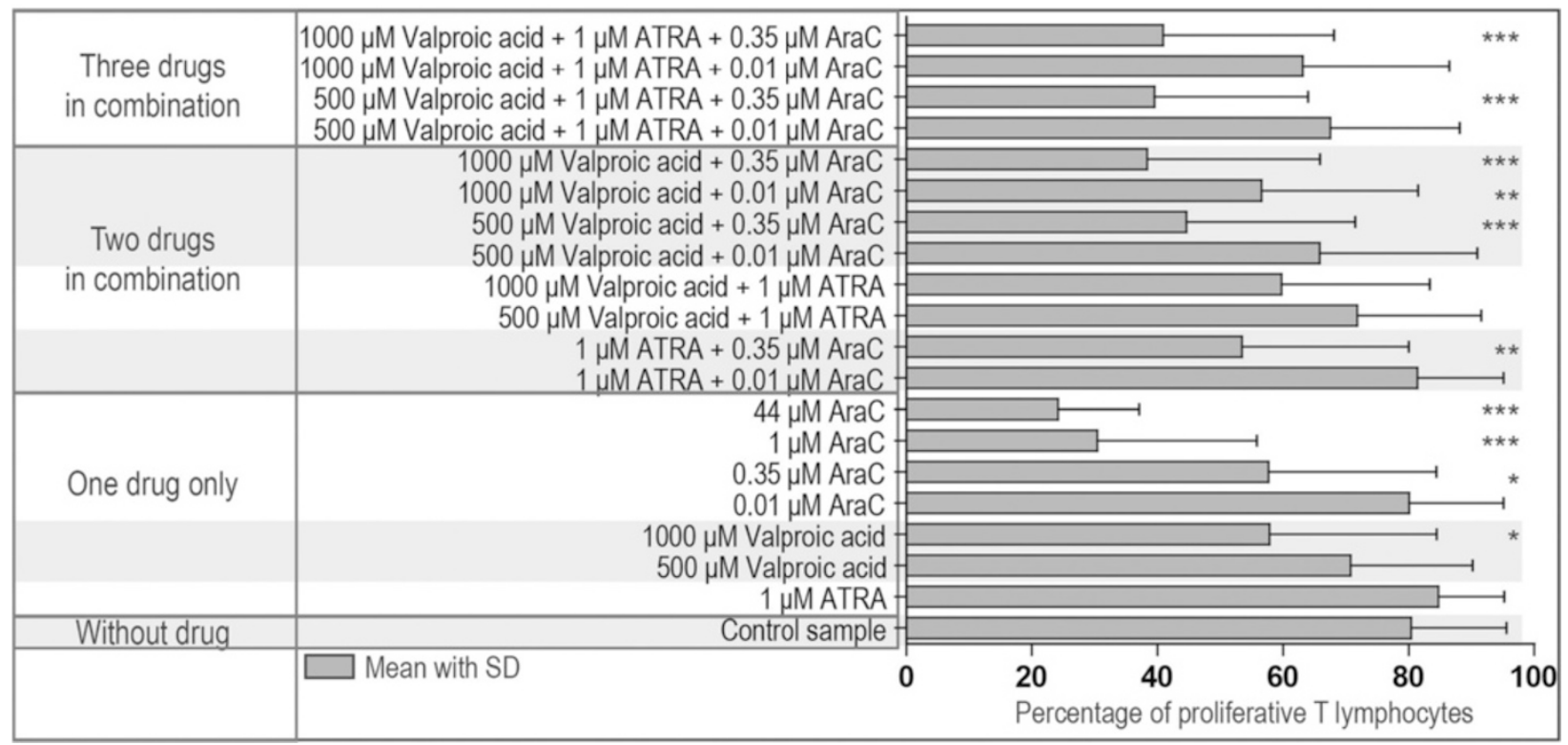

Figure 2 Proliferation of activated T lymphocytes after exposure to cytarabine, ATRA and valproic acid alone or in combinations. PBMCs derived from healthy blood donors $(n=7)$ were stained with the cell proliferation dye CellTrace ${ }^{\mathrm{TM}}$ Violet and subsequently activated by in vitro culture in the presence of anti-CD3 and anti-CD28. Flow cytometric analysis of proliferation was done after 4 days of culture in medium without drugs (control) or in the presence of drugs/drug combinations. (A) The gating strategy to measure the proliferative response of $\mathrm{CD}^{+} \mathrm{T}$ lymphocytes is shown for three representative samples (two control samples - unstimulated and stimulated- and one sample with cytarabine $44 \mu \mathrm{M}$ ). Cultures without anti-CD3 and anti-CD28 and thereby no proliferating cells were used as the negative gating control. (B) The overall results are presented as bar graphs for the control samples and samples exposed to the indicated single drugs or drug combinations. Results are presented as the mean percentages (with SD) of proliferative T cells. A repeated measure ANOVA with Dunnett's Multiple Comparison Test was used to determine statistically significant differences $\left({ }^{*} p<0.05\right.$; ${ }^{* *} p<0.01$; ${ }^{* *} p<0.001$ ).

\section{Valproic acid increases the antiproliferative effect of cytarabine on normal human $\mathrm{T}$ cells}

As described above, normal PBMC were activated in the presence of various drug combinations (Figures 1 and 2 ). Proliferation and viability was not altered for cultures containing various combinations of ATRA and valproic acid, and ATRA alone did not alter the antiproliferative or proapoptotic effects of cytarabine.

Valproic acid 500 and $1000 \mu \mathrm{M}$ was also combined with cytarabine 0.01 and $0.35 \mu \mathrm{M}$; these cytarabine concentrations correspond to the in vivo levels reached during low-dose cytarabine treatment when the drug can be combined with ATRA and valproic acid [15,26,27]. Cytarabine $0.01 \mu \mathrm{M}$ alone did not have any antiproliferative effect but a statistically significant antiproliferative effect was observed when cytarabine at this concentration was combined with valproic acid $1000 \mu \mathrm{M}$ (Figure 2). Similarly, when cytarabine at a higher concentration of $0.35 \mu \mathrm{M}$ was present together with valproic acid an increased antiproliferative effect was observed with valproic 
acid at both $1000 \mu \mathrm{M}$ and $500 \mu \mathrm{M}$. Finally, dual or triple drug combinations did not have significant effects on $\mathrm{T}$ cell viability, the only exception being cytarabine $0.35 \mu \mathrm{M}$ in combination with valproic acid $500 \mu \mathrm{M}$ (Figure 1).
The CD4:CD8 ratio is altered only by high-dose cytarabine but not by ATRA, valproic acid or low-dose cytarabine

Normal PBMCs derived from 3 healthy individuals were activated as described above in the presence of various

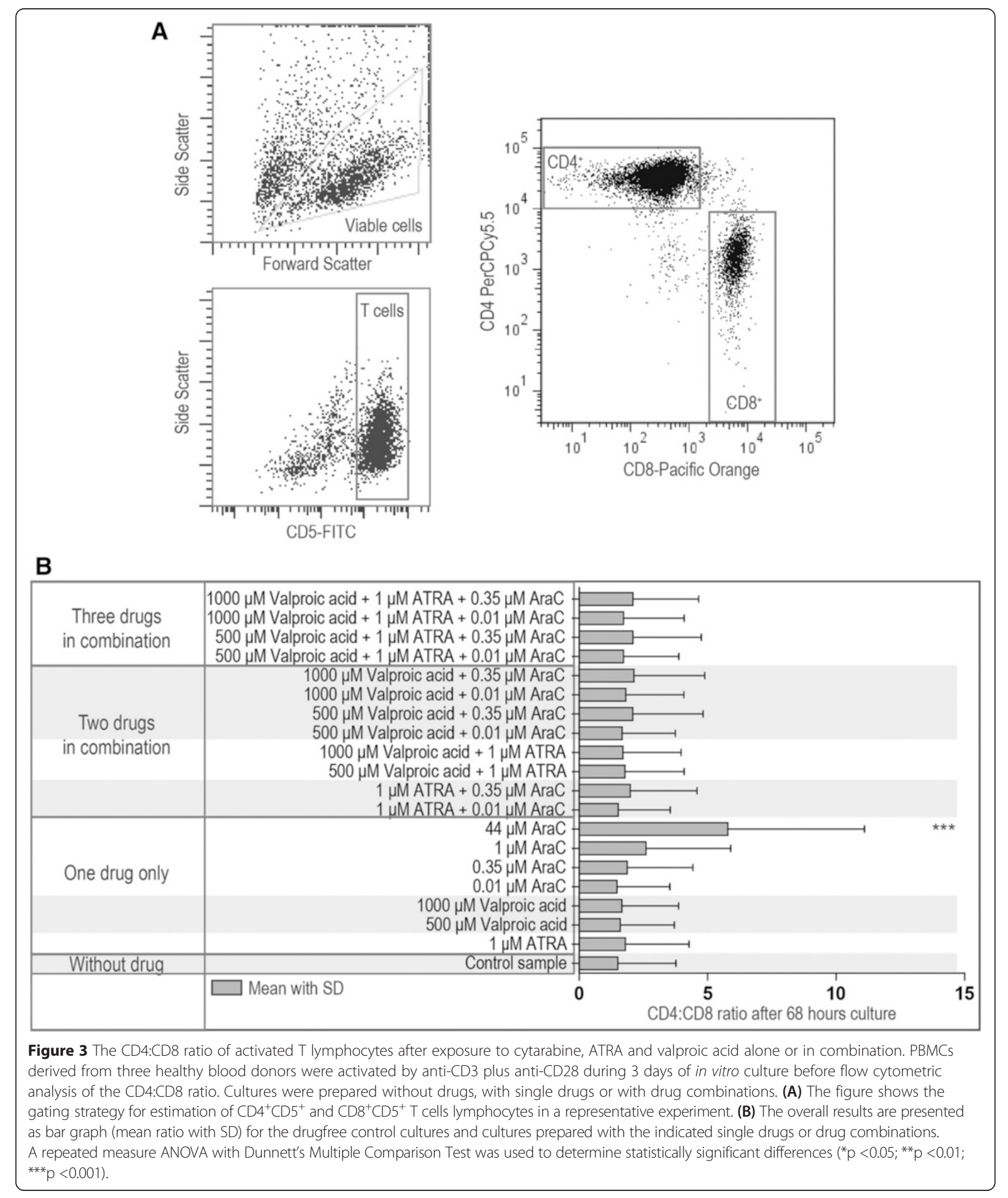




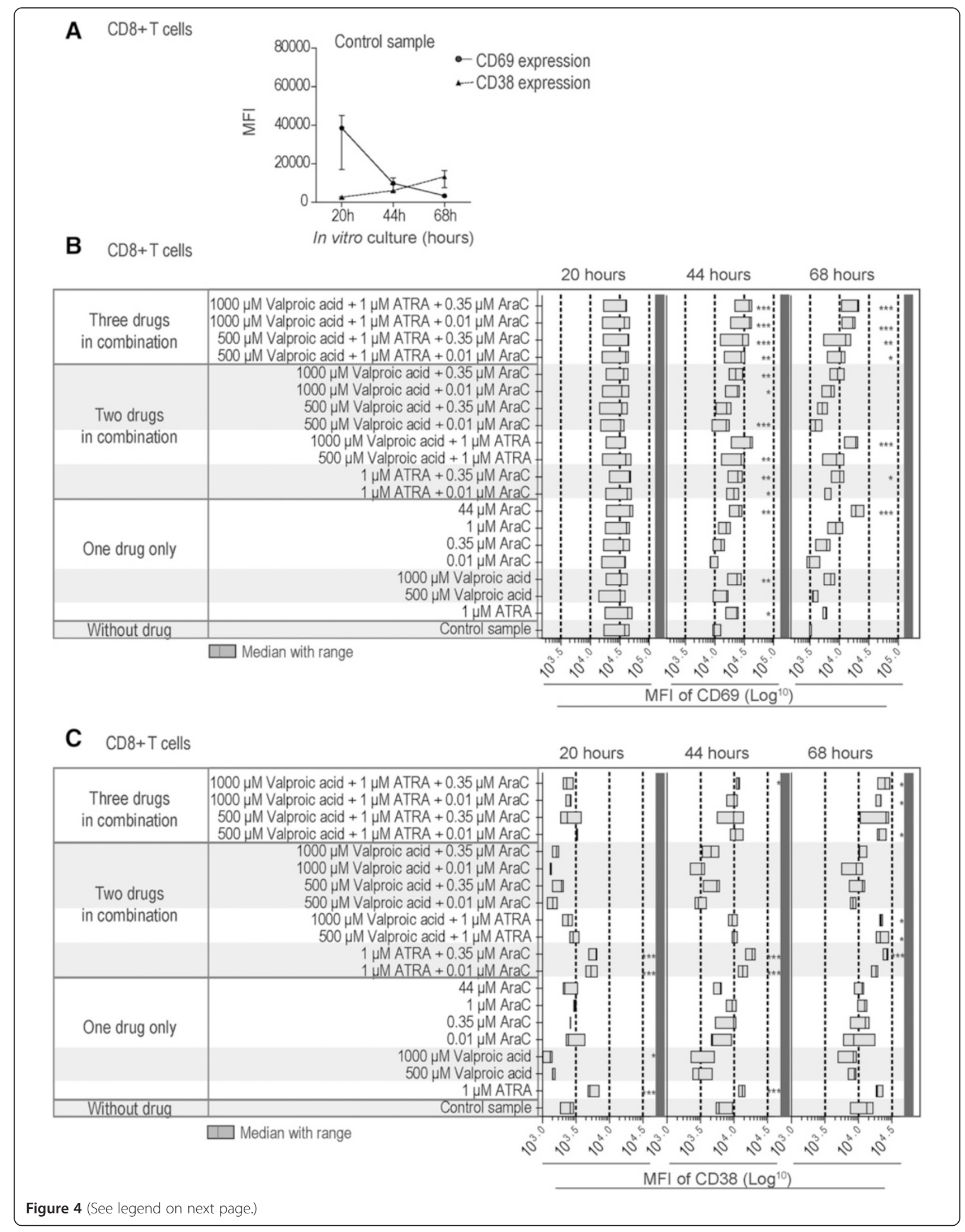


(See figure on previous page.)

Figure 4 Expression of the CD69 and CD38 activation markers by anti-CD3 plus anti-CD28 activated CD8 ${ }^{+}$T lymphocytes - effects of cytarabine, ATRA and valproic acid tested alone or in combination. PBMCs derived from three healthy donors were activated during in vitro culture with anti-CD3 and anti-CD28, and flow-cytometric analysis of surface CD69 and CD38 expression was performed after 20,44, and 68 hours of culture. (A) The figure shows the mean fluorescence intensity (MFI) of surface CD69 and CD38 expression by CD8 ${ }^{+} \mathrm{CD} 5^{+} \mathrm{T}$ lymphocytes in drugfree control cultures after 20,44, and 68 hours (median and range, three experiments). (B) The overall results for CD69 expression are presented as bar graph (median MFI and range) for $\mathrm{CD}^{+} \mathrm{CD}^{+} \mathrm{T}$ lymphocytes cultured in vitro for 20,44 , and 68 hours in the presence of the indicated single drugs or drug combinations. (C) The overall results for CD38 expression are presented as bar graph (median MFI and range) for CD $8^{+} \mathrm{CD} 5^{+} \mathrm{T}$ lymphocytes cultured in vitro for 20,44, and 68 hours in the presence of the indicated single drugs or drug combinations. Repeated measures ANOVA with Dunnett's Multiple Comparison Test was for the statistical analyses $\left({ }^{*} p<0.05 ;{ }^{* *} p<0.01\right.$; ${ }^{* *} p<0.001$ ).

drug combinations. Only cytarabine $(0.35,1.0$ and 44 $\mu \mathrm{M})$ caused a dose-dependent reduction both in viability and proliferation. Proliferation, but not viability, was altered for cultures containing several of the dual or triple drug combinations. However, the CD4:CD8 ratio was significantly increased only by the highest cytarabine concentration of $44 \mu \mathrm{M}$ whereas the ratio was not altered when the cells were cultured with single drugs at the other concentrations or any dual or triple drug combination (Figure 3).

ATRA and valproic acid alters the expression of the CD69 and $\mathrm{CD} 38$ activation markers by $\mathrm{CD}^{+}$and $\mathrm{CD}^{+}$normal $\mathrm{T}$ cells whereas cytarabine has only minor effects

In our experimental model CD69 showed an expected high early expression after 20 hours of culture with antiCD3 plus anti-CD28 both for $\mathrm{CD}_{4}^{+}$and $\mathrm{CD}^{+} \mathrm{T}$ cells, and thereafter it decreased gradually when tested after 44 and 68 hours. In contrast, CD38 showed a gradual increase for both $\mathrm{T}$ cell subsets during the same period after activation (3 healthy individuals tested).

Even though ATRA $1 \mu \mathrm{M}$ and valproic acid 500 and $1000 \mu \mathrm{M}$ had no or only minor effects on T cell proliferation and viability as well as the CD4:CD8 ratio, both drugs prolonged the expression of CD69 both for CD4 ${ }^{+}$ and $\mathrm{CD}^{+} \mathrm{T}$ cells, and significantly increased expression was detected after 44 hours (3 healthy individuals tested, Figures 4 and 5). Cytarabine had a similar increasing effect on CD69 expression for both T cell subsets but only when testing the highest concentration $(44 \mu \mathrm{M})$. The drugs showed additive enhancing effects on CD69 expression both for $\mathrm{CD}^{+}$and $\mathrm{CD}^{+} \mathrm{T}$ cells when testing double or triple combinations, and highly significant differences could then be detected (i) for $\mathrm{CD}^{+} \mathrm{T}$ cells when combining ATRA and valproic acid $500 \mu \mathrm{M}$; and (ii) especially for $\mathrm{CD}^{+}$cells but also $\mathrm{CD}^{+} \mathrm{T}$ cells when ATRA/valproic acid were combined with low cytarabine concentrations (0.01 and $0.35 \mu \mathrm{M}, \mathrm{p}<0.001)$.

ATRA and valproic acid had opposite effects on CD38 expression by activated T cells; ATRA increased the expression whereas valproic acid decreased the early expression of this marker both for $\mathrm{CD}^{+}$and $\mathrm{CD}^{+} \mathrm{T}$ cells. None of these effects were detected after 68 hours. In contrast, cytarabine did not alter CD38 expression for any concentration tested $(0.01,0.35,1$ and $44 \mu \mathrm{M})$. The ATRA-induced enhancement was only maintained in the presence of cytarabine (both for $\mathrm{CD}^{+}$and $\mathrm{CD}^{+} \mathrm{T}$ cells) but not in the presence of ATRA alone. Finally, the valproic acid-induced reduction of CD38 levels was maintained in the presence of cytarabine and the triple combinations did not alter CD38 expression.

Cytarabine $44 \mu \mathrm{M}$ decreased CD25 expression of CD4 ${ }^{+}$ $\mathrm{T}$ cells but only after 68 hours of culture $(\mathrm{p}<0.05)$. No other single drug or drug combinations altered CD25 expression by activated $\mathrm{CD}^{+}$and $\mathrm{CD}^{+}{ }^{+} \mathrm{T}$ cells at any time point tested (data not shown).

\section{The combination of cytarabine, valproic acid and ATRA reduces the release of FasL and HSP90 but have only weak effects on the release of TRAIL and HSP70 by activated $\mathrm{T}$ cells}

Normal PBMC derived from 7 healthy individuals were activated with anti-CD3 and anti-CD28 and cultured for 4 days in vitro with or without valproic acid, ATRA or/ and cytarabine alone or in combination before supernatant levels of FasL, TRAIL HSP70 and HSP90 were determined (Figure 6). Both valproic acid and cytarabine caused a dose-dependent reduction of HSP90 and FasL. However, the reduction in single-drug cultures was relatively small and the most significant decreases were seen for drug combinations and strong reductions were then seen even when combining drugs at concentrations (cytarabine 0.01 and $0.35 \mu \mathrm{M}$, valproic acid $500 \mu \mathrm{M}$ ) that did not cause significant reductions when tested alone. In contrast, the drugs had either no significant or only weak effects on the release of TRAIL and HSP70.

Only high cytarabine concentrations show a broad inhibitory effect on the cytokine release profile by activated $\mathrm{T}$ cell whereas high-level valproic acid as well as combinations of low valproic acid-cytarabine levels inhibits the release of a minor cytokine subset

PBMC derived from 7 healthy individuals were cultured with anti-CD3 plus anti-CD28 for 4 days before supernatant cytokine levels were determined for cultures prepared in medium alone and medium with ATRA $1 \mu \mathrm{M}$, valproic acid 500 and $100 \mu \mathrm{M}$, and cytarabine 0.01, 0.35, 1 and $44 \mu \mathrm{M}$. Each drug was tested alone and in the dual 


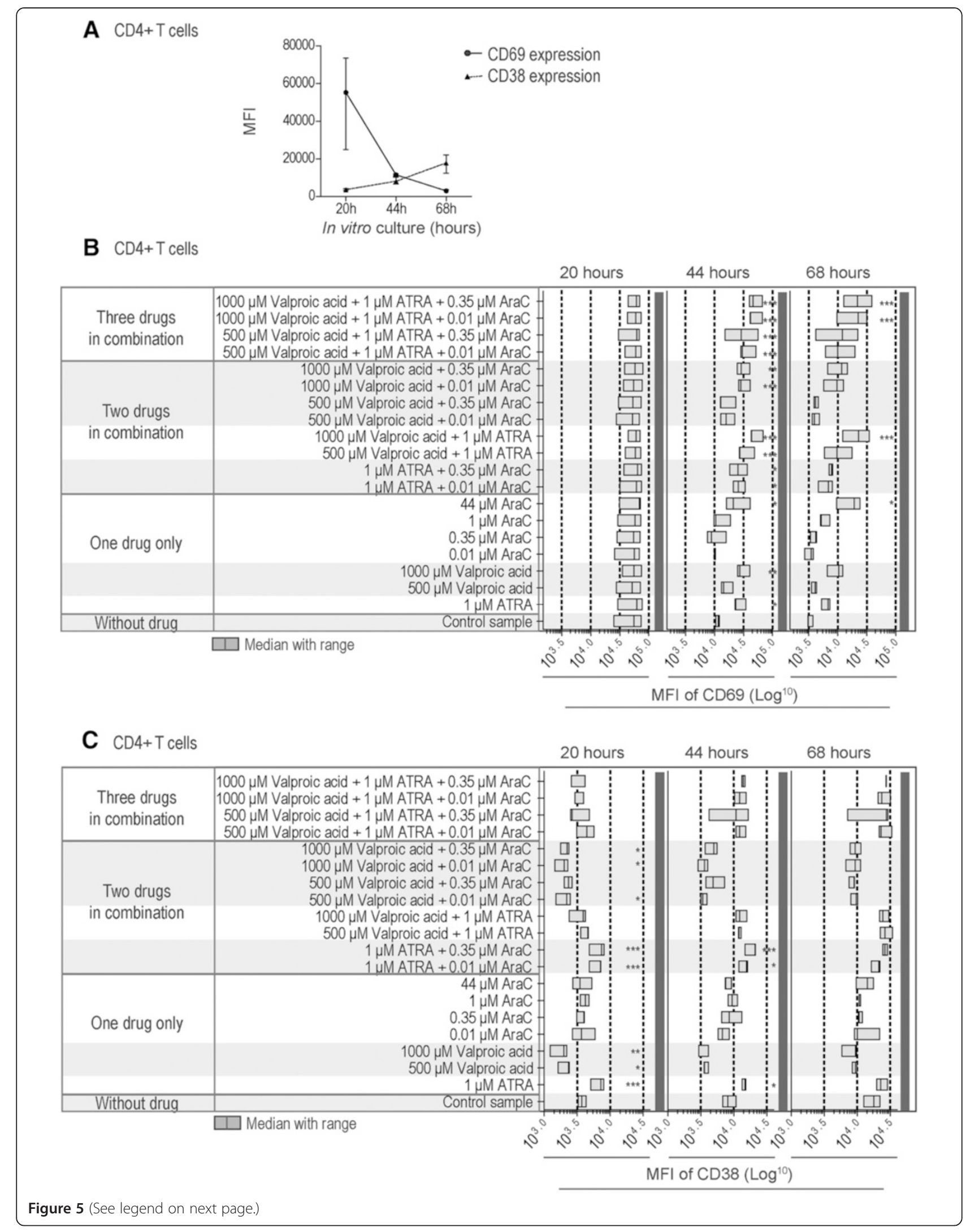


(See figure on previous page.)

Figure 5 Expression of the CD69 and CD38 activation markers by anti-CD3 plus anti-CD28 activated CD4 ${ }^{+}$T lymphocytes - effects of cytarabine, ATRA and valproic acid tested alone or in combination. PBMCs derived from three healthy donors were activated during in vitro culture with anti-CD3 and anti-CD28, and flow-cytometric analysis of surface CD69 and CD38 expression was performed after 20,44, and 68 hours of culture. (A) The figure shows the mean fluorescence intensity (MFI) of surface CD69 and CD38 expression by $C D 4^{+} C D 5^{+} \mathrm{T}$ lymphocytes in drug-free control cultures after 20,44, and 68 hours (median and range, three experiments). (B) The overall results for CD69 expression are presented as bar graph (median MFI and range) for $\mathrm{CD}^{+} \mathrm{CD}^{+} \mathrm{T}$ lymphocytes cultured in vitro for 20,44 , and 68 hours in the presence of the indicated single drugs or drug combinations. (C) The overall results for CD38 expression are presented as bar graph (median MFI and range) for CD4 ${ }^{+} \mathrm{CD} 5^{+} \mathrm{T}$ lymphocytes cultured in vitro for 20,44, and 68 hours in the presence of the indicated single drugs or drug combinations. Repeated measures ANOVA with Dunnett's Multiple Comparison Test was for the statistical analyses $\left({ }^{*} p<0.05\right.$; ${ }^{* *} p<0.01$; $\left.{ }^{* *} p<0.001\right)$.

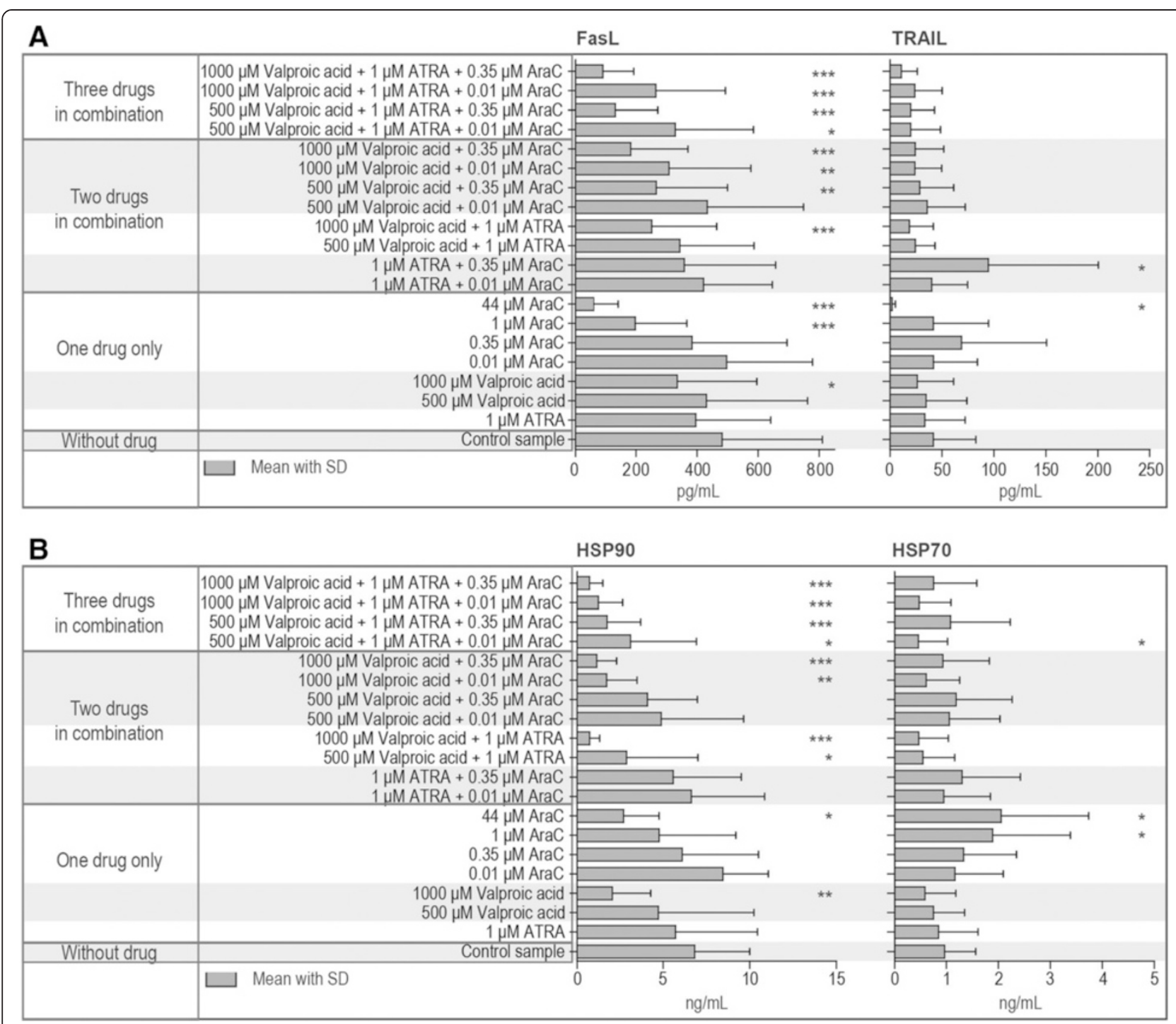

Figure 6 The release of FasL, TRAIL, HSP70 and HSP90 by anti-CD3 plus anti-CD28 activated normal T cells - effects of cytarabine, ATRA and valproic acid tested alone or in combination. The supernatant concentrations of FasL, TRAIL, HSP90 and HSP70 were determined after 4 days of PBMC culture with anti-CD3 plus anti-CD28. Cultures were prepared in medium alone or together with the single drugs or drug combinations indicated in the figures. (A) The upper figure presents the FasL (left panel) and TRAIL (right panel) levels, the lower figure (B) presents the levels of HSP90 (left panel) and HSP70 (right panel). All results are presented as the mean with SD. Repeated measures ANOVA with Dunnett's Multiple Comparison Test against control samples were used for statistical analyses $\left({ }^{*} p<0.05\right.$; ${ }^{* *} p<0.01$; $\left.{ }^{* *} p<0.001\right)$. 
or triple combinations used throughout the study. The overall cytokine results are presented in Additional file 1: Tables S1-S4, and the results are summarized in a twoways hierarchical cluster analysis including 20 cytokines and in addition FasL, TRAIL, HSP70 and HSP90 (Figure 7). We investigated the levels of (i) the immunoregulatory cytokines IFN $\gamma$ and TNF $\alpha$; (ii) the growth factors G-CSF, GM,-CSF, VEGF and bFGF; (iii) the chemokines CCL2-5 and CXCL5; and (iv) the interleukins IL1 $\alpha$, IL1 $\beta$, IL1RA, IL2, IL4-6, IL8, IL10 and IL17. For this two-way hierarchical cluster analysis the cytokine levels in drug-containing cultures were made relative to the level in the corresponding drugfree control, and the mean relative level of each drug-cytokine combination was used for the analysis that included the 24 soluble mediators and the 19 single drug/ drug combinations. The drugs/drug combinations formed three main clusters:

- Only cytarabine $44 \mu \mathrm{M}$ reduced the levels of a majority of the soluble mediators (Figure 7 right margin, lower and upper middle mediator clusters), including HSP90 as well as several chemokines

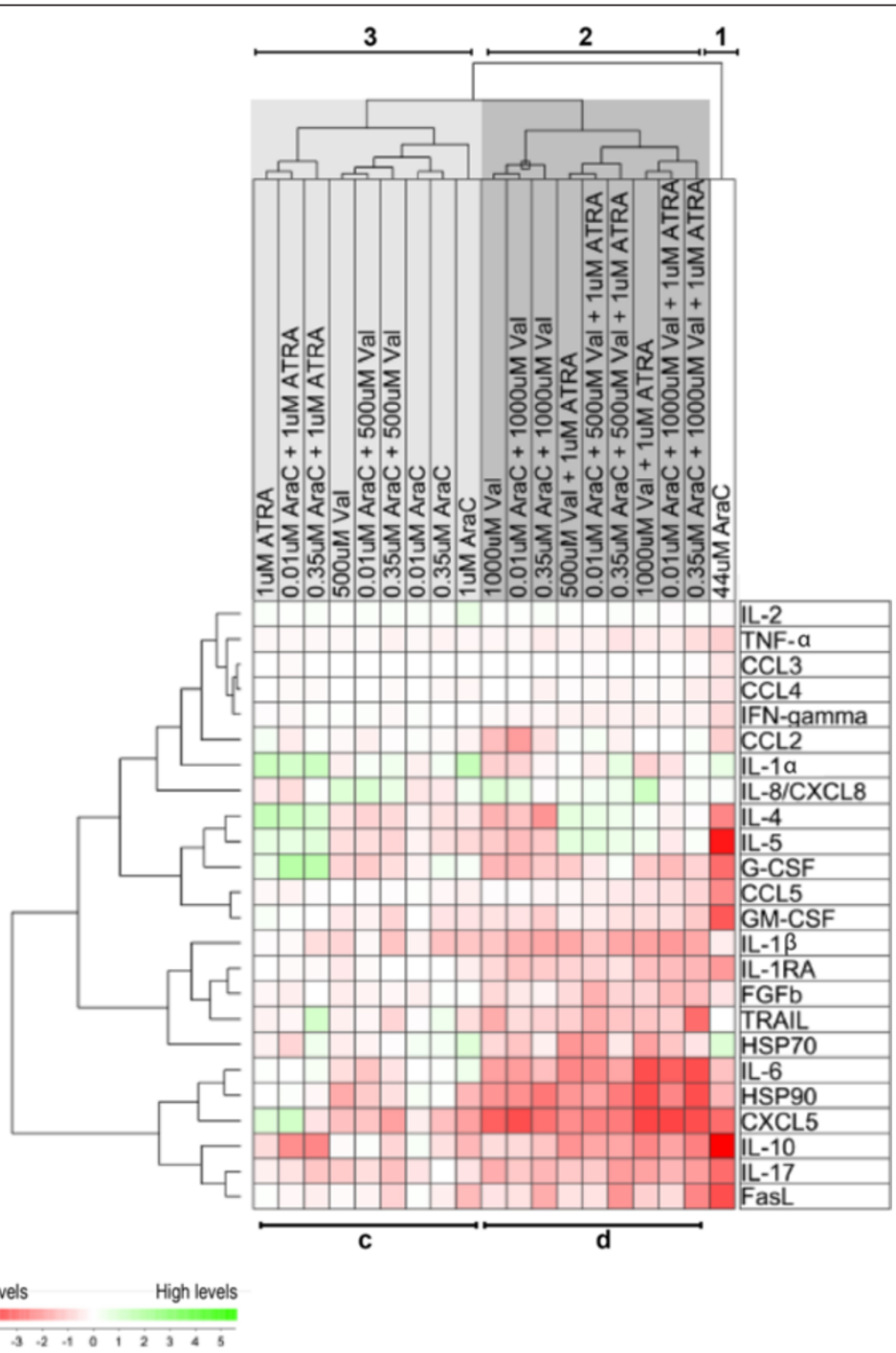

Figure 7 The soluble release profile by activated T cells is altered by valproic acid, ATRA and cytarabine - a two-ways hierarchical cluster analysis. PBMCs derived from 7 healthy individuals were cultured with the T cell activating signal anti-CD3 plus anti-CD28 for 4 days before supernatants were harvested and cytokine levels determined. The cells were then cultured in drugfree control cultures and together with ATRA $1 \mu$ M, valproic acid 500 and $100 \mu \mathrm{M}$, and cytarabine $0.01,0.35,1$ and $44 \mu \mathrm{M}$, and each drug was also tested in dual or triple combinations as indicated at the top of the figure. The overall results are presented in detail in Additional file 1: Table S1-S4. The results from a two-ways hierarchical cluster analysis including FasL, TRAIL, HSP70 and HSP90 together with 20 cytokines are presented in the figure. We investigated the levels of (i) the immunoregulatory cytokines IFNY and TNFa; (ii) the growth factors G-CSF, GM,-CSF, VEGF and bFGF; (iii) the chemokines CCL2-5 and CXCL5; and (iv) the interleukins IL1a, IL1ß, IL1RA, IL2, IL4-6, IL8, IL10 and IL17. The cytokines formed 4 main clusters as indicated on the left margin of the figure. The analysis included the 19 single drug/drug combinations used throughout the study and the various drugs/drug combinations formed three main clusters. 
(CCL5, CXCL5) and immunoregulatory cytokines (IL4-6, IL10, IL17).

- A second cluster was mainly formed by (i) all triple combinations, (ii) the two valproic acid + ATRA combinations and (iii) valproic acid $1000 \mu \mathrm{M}$ tested alone or in combination with low-level cytarabine. This cluster was characterized by decreased release of the lower mediator cluster similar to cytarabine $44 \mu \mathrm{M}$ and in addition a relatively weak effect for the lower middle cluster.

- For the other drugs/combinations we only observed weak and divergent effects.

Thus, only high cytarabine levels show a broad and strong inhibition of the T cell cytokine response, whereas high valproic acid levels $1000 \mu \mathrm{M}$ as well as all triple combinations of low-level cytarabine, low-level valproic acid and ATRA inhibit the release of a defined subset of $\mathrm{T}$ cell derived mediators.

\section{Low cytarabine concentrations show little effect on patient cell viability but significantly reduce their proliferation capability}

We investigated the effect of low-dose cytarabine on cell viability and proliferation for AML cells derived from 48 consecutive patients. As described previously the AML cell viability varies widely between patients after in vitro incubation due to spontaneous in vitro apoptosis [28], and the median viability in our drug-free control cultures was $34 \%$ (range 2-64\%) in the control samples. We investigated cytarabine 0.5, 0.05 and $0.01 \mu \mathrm{M}$ (Figure 8A), and the viability was significantly reduced only for the two highest drug concentrations $(0.5 \mu \mathrm{M}$, median viability $26 \%, \mathrm{p}<0.001 ; 0.05 \mu \mathrm{M}$, median viability $32 \%, \mathrm{p}=0.030$ ). In contrast, all three cytarabine concentrations reduced AML cell proliferation significantly. The median radioactivity corresponded to 5900 counts per minute (cpm) for the drugfree controls (range $<1000-179200$ ), the activity was only $600 \mathrm{cpm}$ for cytarabine $0.5 \mu \mathrm{M}(\mathrm{p}<0.001)$, $900 \mathrm{cpm}$ for cytarabine $0.05 \mu \mathrm{M}(\mathrm{p}<0.001)$ and $1800 \mathrm{cpm}$ for cytarabine $0.01 \mu \mathrm{M}(\mathrm{p}<0.001)$ (Figure $8 \mathrm{~B})$.

\section{Discussion}

Low-toxicity AML-stabilizing treatment is now tried for patients who are unfit for intensive and potentially curative therapy. The HDAC inhibitor valproic acid has been investigated as an antileukemic agent in several clinical studies, usually in combination with ATRA [15] and/or low-dose cytotoxic agents [29]. Three phase II clinical studies have shown that the combination of valproic acid, ATRA and low-dose cytarabine $[15,26,27]$ has low clinical toxicity and can induce complete remission for a minority and disease stabilization for a larger subset of elderly and unfit patients. Despite low clinical toxicity,

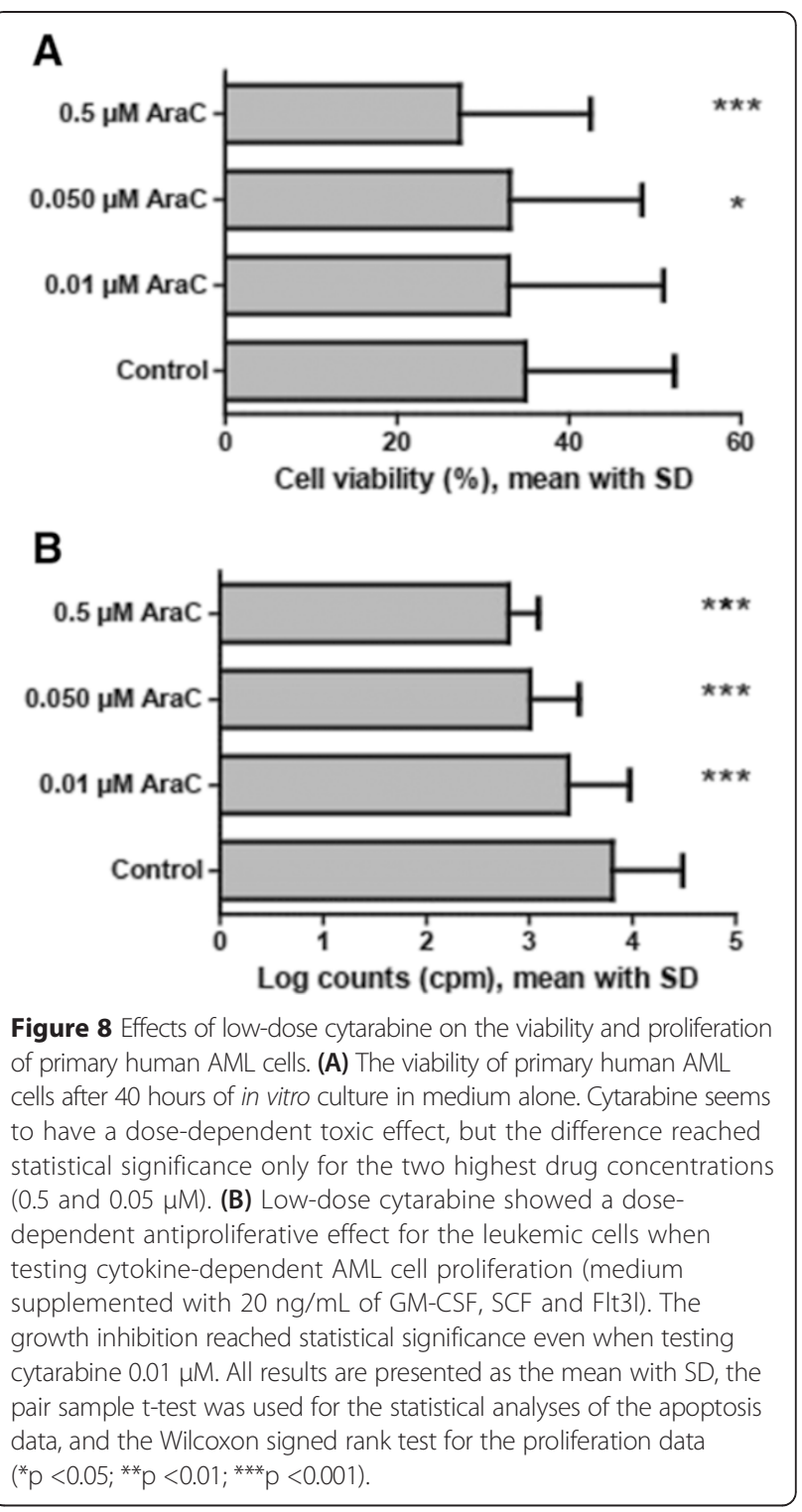

our in vitro results suggest that the treatment may have immunosuppressive effects as we observed decreased T cell viability, reduced $\mathrm{T}$ cell proliferation, altered activationinduced expression of membrane molecules and reduced cytokine release (see Table 1 for summary).

Cytarabine is commonly used in AML therapy and is then used at single doses ranging from $10 \mathrm{mg} / \mathrm{m}^{2}$ up to $3000 \mathrm{mg} / \mathrm{m}^{2}$ [30]. The systemic serum levels therefore show a wide variation depending both on the single dose, the administration form and the gender with faster clearance in males [30]. Firstly, the daily doses commonly used in induction treatment of human AML are $100-200 \mathrm{mg} / \mathrm{m}^{2}$; the drug can then be given as intermittent injections or as continuous infusions and the clearance is also influenced by the pretreatment leukemia blast count in the blood. The average steady state levels 
Table 1 A summary of pharmacological effects on T cell activation; studies of high cytarabine concentrations alone, low cytarabine levels and low cytarabine levels in combination with ATRA and/or valproic acid

\begin{tabular}{|c|c|c|c|}
\hline Parameter & $\begin{array}{l}\text { High cytarabine levels } \\
\text { ( } 44 \text { and } 1.0 \mu \mathrm{M})\end{array}$ & $\begin{array}{l}\text { Low cytarabine } \\
\text { levels }(0.35 \text { and } 0.01 \mu \mathrm{M})\end{array}$ & $\begin{array}{l}\text { Low cytarabine levels }(0.35 \text { and } 0.01 \mu \mathrm{M}) \\
\text { combined with ATRA } 1 \mu \mathrm{M} \text { and/or valproic } \\
\text { acid ( } 500 \text { and } 1000 \mu \mathrm{M})\end{array}$ \\
\hline T cell viability & $\begin{array}{l}\text { Decreased, apoptosis } \\
\text { induction }\end{array}$ & Decreased only for $0.35 \mu \mathrm{M}$ & No significant effect for most combinations \\
\hline T cell proliferation & Decreased & Decreased only for $0.35 \mu \mathrm{M}$ & $\begin{array}{l}\text { A highly significant decrease for combinations } \\
\text { with cytarabine } 0.35 \mu \mathrm{M}\end{array}$ \\
\hline CD4:CD8 ratio & Decreased & No effect & No effect \\
\hline CD69 expression & $\begin{array}{l}\text { Prolonged expression, } \\
\text { especially for } \mathrm{CD}^{+} \text {but } \\
\text { also } \mathrm{CD} 4^{+} \text {cells }\end{array}$ & $\begin{array}{l}\text { No effect both for } \mathrm{CD} 4^{+} \\
\text {and } \mathrm{CD} 8^{+} \text {cells }\end{array}$ & $\begin{array}{l}\mathrm{CD}^{+} \text {cells: Increased by ATRA and decreased } \\
\text { by valproic acid, no effect when combining } \\
\text { these two drugs. The ATRA effect maintaining } \\
\text { when combined with cytarabine. CD } 8^{+} \text {cells: } \\
\text { Increased by ATRA and valproic acid, the } \\
\text { increase was also seen in combinations with } \\
\text { cytarabine. }\end{array}$ \\
\hline CD38 expression & No effect & $\begin{array}{l}\text { No effect both for } \mathrm{CD} 4^{+} \\
\text {and } \mathrm{CD} 8^{+} \text {cells }\end{array}$ & $\begin{array}{l}\mathrm{CD} 4^{+} \text {cells: Increased by ATRA and decreased } \\
\text { by valproic acid, the ATRA effect maintained } \\
\text { in the presence of cytarabine. CD } 8^{+} \text {cells: } \\
\text { Increased by ATRA and decreased by valproic } \\
\text { acid, the ATRA effect maintained in } \\
\text { combinations. }\end{array}$ \\
\hline FasL release & Decreased & No effect & $\begin{array}{l}\text { Strong decrease in all combinations also with } \\
\text { cytarabine } 0.01 \mu \mathrm{M}\end{array}$ \\
\hline TRAIL release & Minor decrease only at $44 \mu \mathrm{M}$ & No effect & Minor effects \\
\hline HSP90 release & Decreased & No effect & $\begin{array}{l}\text { Strong decrease both for cytarabine } 0.35 \text { and } \\
0.01 \mu \mathrm{M}\end{array}$ \\
\hline HSP70 & Increased & No effect & No effect for all except one combination \\
\hline $\begin{array}{l}\text { Cytokine release; } \\
\text { hierarchical cluster } \\
\text { analysis including } 24 \\
\text { soluble mediators }\end{array}$ & $\begin{array}{l}\text { Decreased levels for two out of } 4 \text { main } \\
\text { clusters including } 9 \text { cytokines, including the } \\
\text { cluster showing decreased levels for the drug } \\
\text { combinations. }\end{array}$ & Only minor effects & $\begin{array}{l}\text { Decreased levels only for one out of the four } \\
\text { main clusters, including } 4 \text { cytokines }\end{array}$ \\
\hline
\end{tabular}

during continuous infusions in one study were 0.4 and $0.8 \mu \mathrm{M}$ for 100 and $200 \mathrm{mg} / \mathrm{m}^{2} /$ day, respectively [31]. Levels will be higher when giving these daily doses as injections. Secondly, the drug may also be used at single doses up to $3 \mathrm{~g} / \mathrm{m}^{2}$ twice daily administered as shorttime infusions and resulting in peak concentrations during a 3-hours infusion averaging 50-100 $\mu \mathrm{M}$ [30,31]. Finally, cytarabine is used as low-toxicity subcutaneous injections $\left(10-20 \mathrm{mg} / \mathrm{m}^{2}\right)$ once or twice daily usually for a 10 days period with 4-6 weeks intervals [15]; the steady state levels are then below $0.1 \mu \mathrm{M}[30,32-35]$ and the peak levels after a subcutaneous injection of $10 \mathrm{mg} / \mathrm{m}^{2} / 12$ hours can be up to 0.2-0.5 $\mu \mathrm{M}$ [18]. In our present study we therefore investigated the concentrations (i) $44 \mu \mathrm{M}$ that corresponds to peak levels during high-dose treatment; (ii) $1 \mu \mathrm{M}$ that is reached when using the conventional doses of $100-200 \mathrm{mg} / \mathrm{m}^{2}$; and (iii) and 0.35 and $0.01 \mu \mathrm{M}$ that correspond to levels reached early after and during steady state of low-dose treatment.

Cytarabine effects on $\mathrm{T}$ cell activation were concen tration-dependent; decreased viability was only seen for the higher concentrations and this is in accordance with previous studies suggesting that cytarabine has cytotoxic effects only at concentrations above $100 \mathrm{nM}$ [30]. However, cytarabine had immunoregulatory effects even at lower level. Several of our present observations suggest that the cytarabine effects on activated $\mathrm{T}$ cells at least partly differ between $\mathrm{T}$ cell subsets. This is supported both by (i) the altered $\mathrm{CD} 4: \mathrm{CD} 8$ ratio after exposure to high cytarabine levels, (ii) the differences between $\mathrm{CD} 4^{+}$and $\mathrm{CD} 8^{+} \mathrm{T}$ cells with regard to cytarabine effects on CD38 and CD69 expression during $\mathrm{T}$ cell activation; and (iii) previous studies describing that in vivo treatment with our triple combination causes normalization of the increased pre-therapy levels of circulating Treg cells, whereas the levels of circulating Th17 cells are not affected by the treatment [15].

Cytarabine decreased AML cell viability only when tested at 0.5 and $0.05 \mu \mathrm{M}$ but not at the lowest concentration, whereas the drug inhibited AML cell proliferation even at $0.01 \mu \mathrm{M}$. In contrast, $\mathrm{T}$ cell proliferation was inhibited only at cytarabine concentrations $\geq 0.35 \mu \mathrm{M}$. Thus, based on the proliferation studies we conclude that primary AML cells are more susceptible to cytarabine than normal $\mathrm{T}$ cells; suggesting that there is a therapeutic window for cytarabine treatment that makes it possible to achieve antileukemic effects in vivo before severe $\mathrm{T}$ cell toxicity occurs. 
Our in vitro studies showed that valproic acid alone affected $\mathrm{T}$ cell activation but only for a minority of our experimental models and usually when testing the highest concentration of $1000 \mu \mathrm{M}$ that corresponds to a level slightly above the recommended therapeutic serum level [15]. ATRA did not affect $\mathrm{T}$ cell activation in most of our studies. However, both drugs contributed to the effects of the triple combination of T cell activation, and in several of our models highly significant immunomodulatory effects were seen only when testing the triple combination.

Early lymphoid reconstitution after intensive and potentially curative antileukemic therapy is associated with decreased risk of later AML relapse, suggesting that post-treatment immunological events are clinically important to maintain disease control and complete hematological remission after end of treatment $[36,37]$. This association between early lymphoid reconstitution and survival has also been observed after conventional intensive chemotherapy [3], autotransplantation [4] and allotransplantation $[5,6]$. The mechanisms behind this association are not known [38], but taken together these observations suggest that not only allogeneic but also autologous antileukemic $\mathrm{T}$ cell reactivity after intensive treatment or autotransplantation is clinically important.

To the best of our knowledge no previous studies have investigated whether such autologous antileukemic $\mathrm{T}$ cell reactivity is important also in patients receiving AML-stabilizing treatment, e.g. the combination of ATRA, valproic acid and cytarabine. There are two major differences between AML patients receiving intensive treatment and patients receiving our low-toxicity triple combination: (i) most patients receiving stabilizing treatment do not achieve complete hematological remission, and (ii) these patients will often receive continued therapy until disease progression. Furthermore, many AML patients have severe leucopenia, including $\mathrm{T}$ lymphopenia [16]. During the continued AMLstabilizing treatment most of these patients thus have a combined AML-induced quantitative and treatmentinduced qualitative $\mathrm{T}$ cell effect. Most of the patients who respond to the treatment do not show increased leukocyte counts [16,39]. If antileukemic immune reactivity is important for the efficiency of AML-stabilizing treatment similar to its effect in patients receiving intensive therapy, the immunosuppressive effects described in our present study may influence the efficiency of this treatment. The question should be addressed in future clinical studies, and one should then especially investigate whether the effect differs between various $\mathrm{T}$ cell subsets.

Three clinical studies have previously investigated the antileukemic effect of low-dose cytarabine, ATRA and valproic acid $[13,39,40]$, but the question of immunosuppression was only addressed in one of them [39]. This study showed that even though the drug-induced immunosuppression may be important for the antileukemic efficiency of AML-stabilizing (see above), the triple combination does not seem to have a major impact on the risk of complicating infections in responders to the treatment as these patients usually stayed outside hospital without severe infections as long as the disease was stable without signs of AML progression [39]. However, it should be emphasized that these patients were treated with even a lower cytarabine dose than commonly used for low-dose cytarabine treatment [39], and in contrast to the other two studies ATRA was administered as an intermittent therapy with 2 weeks of treatment at 12 weeks intervals. Our studies suggest that clinically relevant immunosuppression may occur if standard low-dose cytarabine or continuous ATRA therapy is used.

The valproic acid-ATRA-cytarabine combination altered $\mathrm{T}$ cell release of several soluble mediators. Firstly, FasL (CD95L) and TNF-related apoptosis-inducing ligand (TRAIL or APO2) may mediate autocrine activationinduced cell death (AICD) to maintain self-tolerance and suppress immune responses [41,42], but soluble CD95L may also induce non-apoptotic signals that promote cell migration [43]. The effects of single drugs and especially our triple combination on FasL release suggest that the treatment may alter cell trafficking. Secondly, the intracellular chaperones HSP90 and HSP70 can be released extracellularly and will then have immunomodulatory effects [44-47]; these effects may be affected by the altered HSP90 levels during T cell activation in the presence of our triple combination. Finally, both cytarabine, valproic acid and ATRA affected the release of several interleukins and chemokines by activated $\mathrm{T}$ cells. Taken together these observations suggest that the antileukemic triple combination not only has direct effects on $\mathrm{T}$ cells, but probably also indirect effects on other immunocompetent cells mediated by the altered release of soluble mediators during $\mathrm{T}$ cell activation.

\section{Conclusions}

Both previous in vivo studies and the present in vitro studies suggest that the triple combination of low-dose cytarabine, ATRA and valproic acid has immunomodulatory effects, and as discussed above these effects may differ between various $\mathrm{T}$ cell subsets. The triple combination has direct effects on the T cells, but it may also affect other immunocompetent cells through the altered release of soluble mediators during $\mathrm{T}$ cell activation. This possible risk of immunosuppression should be further investigated in future clinical studies. 


\section{Additional file}

Additional file 1: Table S1. Supernatant levels of immunomodulatory cytokines and growth factors. Table S2. Supernatant levels of chemokines.

Table S3. Supernatant levels of Interleukins (IL-1 - IL-5). Table S4. Supernatant levels of Interleukins (IL-6 - IL-17).

\section{Abbreviations}

AML: Acute myeloid leukemia; ATRA: All-trans retinoic acid; ELISA: Enzymelinked immuno-sorbent analyses (ELISA); HSP: Heat shock protein; PBMC: Peripheral blood mononuclear cells.

\section{Competing interests}

The authors declare that they have no competing interests.

\section{Authors' contributions}

$\mathrm{EE}, \mathrm{AKB}$ and $\mathrm{KV}$ designed and performed experiments, analyzed data and wrote the manuscript. HR performed cluster analyses, interpreted the data and revised the manuscript. $\varnothing \mathrm{B}$ conceived and guided the study, and wrote the manuscript. All authors read and approved the final manuscript.

\section{Acknowledgements}

This work was supported by Helse-Vest and Norwegian Cancer Society. The technical assistance of Kristin Paulsen is highly appreciated. Parts of the ELISA and Luminex results are based upon the work done by the following bachelor-students: Hilde V. Edvardsen, Trude B. Grannes, Marthe D. Johnsen, Janicke Danielsen and Trude Nordal.

\section{Author details}

${ }^{1}$ Institute of Clinical Science, University of Bergen, Bergen, Norway. ${ }^{2}$ Institute of Biomedical Laboratory Sciences, Bergen University College, Nygårdsgaten 112, P.O. Box 7030, N-5020 Bergen, Norway. ${ }^{3}$ Department of Medicine, Haukeland University Hospital, Bergen, Norway.

Received: 13 November 2014 Accepted: 21 April 2015

Published online: 02 May 2015

\section{References}

1. Liseth K, Sjo M, Paulsen K, Bruserud O, Ersvaer E. Early pre-engraftment, functional, in vitro responsiveness of T lymphocytes in allotransplanted, acute leukemia patients: proliferation and release of a broad profile of cytokines, possibly predictive of graft-versus-host disease. Eur Cytokine Netw. 2010;21(1):40-9.

2. Mackall C, Fry T, Gress R, Peggs K, Storek J, Toubert A, et al. Background to hematopoietic cell transplantation, including post transplant immune recovery. Bone Marrow Transplant. 2009:44(8):457-62.

3. Behl D, Porrata LF, Markovic SN, Letendre L, Pruthi RK, Hook CC, et al. Absolute lymphocyte count recovery after induction chemotherapy predicts superior survival in acute myelogenous leukemia. Leukemia. 2006;20(1):29-34.

4. Porrata LF, Litzow MR, Tefferi A, Letendre L, Kumar S, Geyer SM, et al. Early lymphocyte recovery is a predictive factor for prolonged survival after autologous hematopoietic stem cell transplantation for acute myelogenous leukemia. Leukemia. 2002;16(7):1311-8.

5. Parkman R, Cohen G, Carter SL, Weinberg Kl, Masinsin B, Guinan E, et al. Successful immune reconstitution decreases leukemic relapse and improves survival in recipients of unrelated cord blood transplantation. Biol Blood Marrow Transplant. 2006;12(9):919-27.

6. Kim DH, Sohn SK, Won DI, Lee NY, Suh JS, Lee KB. Rapid helper T-cell recovery above $200 \times 106 / 1$ at 3 months correlates to successful transplant outcomes after allogeneic stem cell transplantation. Bone Marrow Transplant. 2006;37(12):1119-28.

7. Colotta F, Allavena P, Sica A, Garlanda C, Mantovani A. Cancer-related inflammation, the seventh hallmark of cancer: links to genetic instability. Carcinogenesis. 2009;30(7):1073-81.

8. Smith M, Barnett M, Bassan R, Gatta G, Tondini C, Kern W. Adult acute myeloid leukaemia. Crit Rev Oncol Hematol. 2004;50(3):197-222.

9. Fredly $H$, Reikvam H, Gjertsen BT, Bruserud O. Disease-stabilizing treatment with all-trans retinoic acid and valproic acid in acute myeloid leukemia: serum hsp70 and hsp90 levels and serum cytokine profiles are determined by the disease, patient age, and anti-leukemic treatment. Am J Hematol. 2012:87(4):368-76.

10. Schlenk RF, Frohling S, Hartmann F, Fischer JT, Glasmacher A, del Valle F, et al. Phase III study of all-trans retinoic acid in previously untreated patients 61 years or older with acute myeloid leukemia. Leukemia. 2004;18(11):1798-803.

11. Kuendgen A, Knipp S, Fox F, Strupp C, Hildebrandt B, Steidl C, et al. Results of a phase 2 study of valproic acid alone or in combination with all-trans retinoic acid in 75 patients with myelodysplastic syndrome and relapsed or refractory acute myeloid leukemia. Ann Hematol. 2005;84 Suppl 1:61-6.

12. Raffoux E, Chaibi P, Dombret H, Degos L. Valproic acid and all-trans retinoic acid for the treatment of elderly patients with acute myeloid leukemia. Haematologica. 2005;90(7):986-8.

13. Bug G, Ritter M, Wassmann B, Schoch C, Heinzel T, Schwarz K, et al. Clinical trial of valproic acid and all-trans retinoic acid in patients with poor-risk acute myeloid leukemia. Cancer. 2005;104(12):2717-25.

14. Venditti A, Stasi R, Del Poeta G, Buccisano F, Aronica G, Bruno A, et al. Alltrans retinoic acid and low-dose cytosine arabinoside for the treatment of 'poor prognosis' acute myeloid leukemia. Leukemia. 1995;9(7):1121-5.

15. Fredly $\mathrm{H}$, Gjertsen $\mathrm{BT}$, Bruserud $\mathrm{O}$. Histone deacetylase inhibition in the treatment of acute myeloid leukemia: the effects of valproic acid on leukemic cells, and the clinical and experimental evidence for combining valproic acid with other antileukemic agents. Clinical epigenetics. 2013;5(1):12.

16. Ryningen A, Stapnes C, Lassalle P, Corbascio M, Gjertsen BT, Bruserud O. A subset of patients with high-risk acute myelogenous leukemia shows improved peripheral blood cell counts when treated with the combination of valproic acid, theophylline and all-trans retinoic acid. Leuk Res. 2009;33(6):779-87.

17. Yamauchi T, Kawai Y, Kishi S, Goto N, Urasaki Y, Imamura S, et al. Monitoring of intracellular 1-beta-D-arabinofuranosylcytosine 5'-triphosphate in 1-betaD-arabinofuranosylcytosine therapy at low and conventional doses. Jpn J Cancer Res. 2001;92(5):546-53.

18. Ishikura H, Sawada H, Okazaki T, Mochizuki T, Izumi Y, Yamagishi M, et al. The effect of low dose Ara-C in acute nonlymphoblastic leukaemias and atypical leukaemia. Br J Haematol. 1984;58(1):9-18.

19. Ueda T, Matsuyama S, Yamauchi T, Kishi S, Fukushima T, Tsutani H, et al. Clinical pharmacology of intermediate and low-dose cytosine arabinoside (ara-C) therapy in patients with hematologic malignancies. Adv Exp Med Biol. 1998:431:647-51.

20. Trus MR, Yang L, Suarez Saiz F, Bordeleau L, Jurisica I, Minden MD. The histone deacetylase inhibitor valproic acid alters sensitivity towards all trans retinoic acid in acute myeloblastic leukemia cells. Leukemia. 2005:19(7):1161-8.

21. Ertesvag A, Engedal N, Naderi S, Blomhoff HK. Retinoic acid stimulates the cell cycle machinery in normal T cells: involvement of retinoic acid receptor-mediated IL-2 secretion. J Immunol. 2002;169(10):5555-63.

22. Breitman TR, Selonick SE, Collins SJ. Induction of differentiation of the human promyelocytic leukemia cell line ( $\mathrm{HL}-60)$ by retinoic acid. Proc Natl Acad Sci U S A. 1980;77(5):2936-40.

23. DeAngelis LM, Kreis W, Chan K, Dantis E, Akerman S. Pharmacokinetics of ara-C and ara- $U$ in plasma and CSF after high-dose administration of cytosine arabinoside. Cancer Chemother Pharmacol. 1992;29(3):173-7.

24. Hiddemann W. Cytosine arabinoside in the treatment of acute myeloid leukemia: the role and place of high-dose regimens. Ann Hematol. 1991:62(4):119-28

25. Bruserud O, Hovland R, Wergeland L, Huang TS, Gjertsen BT. Flt3-mediated signaling in human acute myelogenous leukemia (AML) blasts: a functional characterization of Flt3-ligand effects in AML cell populations with and without genetic Flt3 abnormalities. Haematologica. 2003;88(4):416-28.

26. Corsetti MT, Salvi F, Perticone S, Baraldi A, De Paoli L, Gatto S, et al. Hematologic improvement and response in elderly AML/RAEB patients treated with valproic acid and low-dose Ara-C. Leuk Res. 2011;35(8):991-7.

27. Lane S, Gill D, McMillan NA, Saunders N, Murphy R, Spurr T, et al. Valproic acid combined with cytosine arabinoside in elderly patients with acute myeloid leukemia has in vitro but limited clinical activity. Leuk Lymphoma. 2012;53(6):1077-83.

28. Ryningen A, Ersvaer E, Oyan AM, Kalland KH, Vintermyr OK, Gjertsen BT, et al. Stress-induced in vitro apoptosis of native human acute myelogenous leukemia (AML) cells shows a wide variation between patients and is associated with low BCL-2:Bax ratio and low levels of heat shock protein 70 and 90. Leuk Res. 2006;30(12):1531-40. 
29. Fredly H, Stapnes Bjornsen C, Gjertsen BT, Bruserud O. Combination of the histone deacetylase inhibitor valproic acid with oral hydroxyurea or 6-mercaptopurin can be safe and effective in patients with advanced acute myeloid leukaemia-a report of five cases. Hematology. 2010;15(5):338-43.

30. Hubeek I, Kaspers G-JL, Ossenkoppele GJ, Peters GJ. Deoxynucleoside analogs in cancer therapy. In: Peter GJ, editor. Cancer Drug Discovery and Development. 2006. p. 119-52. View at Google Scholar.

31. Cole N, Gibson BE. High-dose cytosine arabinoside in the treatment of acute myeloid leukaemia. Blood Rev. 1997;11(1):39-45.

32. Papayannopoulou T, de Ron Torrealba A, Veith R, Knitter G, Stamatoyannopoulos G. Arabinosylcytosine induces fetal hemoglobin in baboons by perturbing erythroid cell differentiation kinetics. Science. 1984;224(4649):617-9.

33. Fleming RA, Capizzi RL, Rosner GL, Oliver LK, Smith SJ, Schiffer CA, et al. Clinical pharmacology of cytarabine in patients with acute myeloid leukemia: a cancer and leukemia group B study. Cancer Chemother Pharmacol. 1995;36(5):425-30

34. Kreis W, Chaudhri F, Chan K, Allen S, Budman DR, Schulman P, et al. Pharmacokinetics of low-dose 1-beta-D-arabinofuranosylcytosine given by continuous intravenous infusion over twenty-one days. Cancer Res. 1985;45(12 Pt 1):6498-501.

35. Spriggs D, Griffin J, Wisch J, Kufe D. Clinical pharmacology of low-dose cytosine arabinoside. Blood. 1985;65(5):1087-9.

36. Williams KM, Hakim FT, Gress RE. T cell immune reconstitution following Iymphodepletion. Semin Immunol. 2007;19(5):318-30.

37. Auletta JJ, Lazarus HM. Immune restoration following hematopoietic stem cell transplantation: an evolving target. Bone Marrow Transplant. 2005:35(9):835-57.

38. Obeid M, Tesniere A, Panaretakis T, Tufi R, Joza N, van Endert P, et al. Ectocalreticulin in immunogenic chemotherapy. Immunol Rev. 2007;220:22-34

39. Fredly H, Ersvaer E, Kittang AO, Tsykunova G, Gjertsen BT, Bruserud O. The combination of valproic acid, all-trans retinoic acid and low-dose cytarabine as disease-stabilizing treatment in acute myeloid leukemia. Clinical epigenetics. 2013;5(1):13.

40. Cimino G, Lo-Coco F, Fenu S, Travaglini L, Finolezzi E, Mancini M, et al. Sequential valproic acid/all-trans retinoic acid treatment reprograms differentiation in refractory and high-risk acute myeloid leukemia. Cancer Res. 2006;66(17):8903-11.

41. Monleon I, Martinez-Lorenzo MJ, Monteagudo L, Lasierra P, Taules M, Iturralde $M$, et al. Differential secretion of Fas ligand- or APO2 ligand/TNF-related apoptosis-inducing ligand-carrying microvesicles during activation-induced death of human T cells. J Immunol. 2001;167(12):6736-44.

42. Martinez-Lorenzo MJ, Anel A, Gamen S, Monle nl, Lasierra P, Larrad L, et al. Activated human T cells release bioactive Fas ligand and APO2 ligand in microvesicles. J Immunol. 1999;163(3):1274-81.

43. Tauzin S, Chaigne-Delalande B, Selva E, Khadra N, Daburon S, Contin-Bordes C, et al. The naturally processed CD95L elicits a c-yes/calcium/PI3K-driven cell migration pathway. PLoS Biol. 2011;9(6), e1001090.

44. Calderwood SK, Theriault JR, Gong J. Message in a bottle: role of the 70-kDa heat shock protein family in anti-tumor immunity. Eur J Immunol. 2005;35(9):2518-27.

45. Chen T, Cao X. Stress for maintaining memory: HSP70 as a mobile messenger for innate and adaptive immunity. Eur J Immunol. 2010;40(6):1541-4.

46. Barreto A, Gonzalez JM, Kabingu E, Asea A, Fiorentino S. Stress-induced release of HSC70 from human tumors. Cell Immunol. 2003;222(2):97-104.

47. Broquet $\mathrm{AH}$, Thomas $\mathrm{G}$, Masliah J, Trugnan G, Bachelet M. Expression of the molecular chaperone Hsp70 in detergent-resistant microdomains correlates with its membrane delivery and release. J Biol Chem. 2003;278(24):21601-6.

\section{Submit your next manuscript to BioMed Central and take full advantage of:}

- Convenient online submission

- Thorough peer review

- No space constraints or color figure charges

- Immediate publication on acceptance

- Inclusion in PubMed, CAS, Scopus and Google Scholar

- Research which is freely available for redistribution

Submit your manuscript at www.biomedcentral.com/submit 